\title{
Determination of Efavirenz in Diluted Alkaline Electrolyte by Cathodic Adsorptive Stripping Voltammetry at the Mercury Film Electrode
}

\author{
Arnaldo A. Castro, ${ }^{a, b}$ Marcus V. N. de Souza, ${ }^{c}$ Nicolás A. Rey ${ }^{*, a}$ and Percio A. M. Farias ${ }^{a}$ \\ ${ }^{a}$ Departmento de Química, Pontifícia Universidade Católica do Rio de Janeiro, \\ Rua Marquês de São Vicente no. 225, 22453-900 Rio de Janeiro-RJ, Brazil
}

${ }^{b}$ Facultad de Química, Química Analítica, Universidad de La Habana, CP 10400, Ciudad de la Habana, Cuba

'Instituto de Tecnologia em Fármacos-FarManguinhos, Fundação Oswaldo Cruz, Av. Comandante Guaranys no. 447, Jacarepaguá, 22775-903 Rio de Janeiro-RJ, Brazil

Um método de redissolução para a determinação do agente anti-retroviral efavirenz em concentrações submicromolares e meio eletrolítico alcalino diluído é descrito. As condições experimentais ótimas encontradas são: $\mathrm{NaOH} 2,0 \times 10^{-3} \mathrm{~mol} \mathrm{~L}^{-1}$, potencial de acumulação $-0,10 \mathrm{~V}$, amplitude de pulso $50 \mathrm{mV}$ e velocidade de varredura $50 \mathrm{mV} \mathrm{s}^{-1}$. A resposta é linear sobre a faixa de concentrações 0,01-0,25 ppm. Para um tempo de acumulação de 10 min, o limite de detecção encontrado foi igual a $1,0 \mathrm{ppb}\left(3,0 \times 10^{-9} \mathrm{~mol} \mathrm{~L}^{-1}\right)$. As condições mais convenientes para a medida da concentração de efavirenz na presença de ATP, DNA, diversos metais e outros antivirais foi também investigada. A utilidade do método é demonstrada pela determinação de efavirenz em uma mistura sintética contendo lamivudina e zidovudina, drogas frequentemente usadas na clínica em associação com o efavirenz como parte da terapêutica anti-retroviral de alta ação (HAART).

A stripping method for the determination of the antiretroviral drug efavirenz at the submicromolar concentration levels in diluted alkaline electrolyte is described. Optimum experimental conditions were: $2.0 \times 10^{-3} \mathrm{~mol} \mathrm{~L}^{-1} \mathrm{NaOH}$, accumulation potential of $-0.10 \mathrm{~V}$, pulse amplitude of $50 \mathrm{mV}$ and scan rate of $50 \mathrm{mV} \mathrm{s}^{-1}$. The response is linear over the concentration range of 0.01-0.25 ppm. For an accumulation time of $10 \mathrm{~min}$, the limit of detection was $1.0 \mathrm{ppb}$ $\left(3.0 \times 10^{-9} \mathrm{~mol} \mathrm{~L}^{-1}\right)$. The most convenient conditions to measure the efavirenz concentration in the presence of ATP, DNA, several metals, and other antiviral drugs was also investigated. The utility of the method is demonstrated by the determination of efavirenz in a synthetic mixture containing both lamivudine and zidovudine, which are frequently used in the clinic in association with efavirenz as part of highly active antiretroviral therapy (HAART).

Keywords: efavirenz determination, antiviral drugs, metals, thin-film mercury electrode, differential pulse scan stripping voltammetry

\section{Introduction}

Efavirenz (brand names Sustiva ${ }^{\mathrm{TM}}$ and Stocrin ${ }^{\mathrm{TM}}$, Figure 1) is a non-nucleoside reverse transcriptase inhibitor (NNRTI) and is used as part of highly active antiretroviral therapy for the treatment of human immunodeficiency virus (HIV) type 1. These drugs stop HIV from multiplying by preventing the reverse transcriptase enzyme from working. This enzyme transcribes HIV genetic material (singlestranded RNA) into double-stranded DNA. This step has to occur before HIV genetic code gets inserted into the

*e-mail: nicoarey@puc-rio.br genetic code of an infected cell. Efavirenz is also used in combination with other antiretroviral agents as part of an expanded post-exposure prophylaxis regimen to reduce the

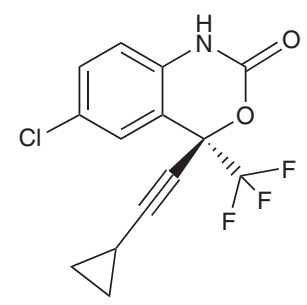

Figure 1. Chemical structure of efavirenz, [(4S)-6-chloro-4-(2cyclopropylethynyl)-4-(trifluoromethyl)-2,4-dihydro-1H-3,1-benzoxazin2-one]. 
hazard of HIV infection in people exposed to a significant risk (e.g. needlestick injuries, certain types of unprotected sex etc). Current guidelines for the management of HIV patients suggest the use of two nucleoside reverse transcriptase inhibitors (NRTIs), such as lamivudine and zidovudine, in combination with a NNRTI, such as efavirenz..$^{1-3}$ Lamivudine and zidovudine are present in the popular HIV medication Combivir ${ }^{\mathrm{TM}}$. Recently, efavirenz began to be produced in Brazil on request of the Ministry of Health.

Several chromatographic ${ }^{4-15}$ and spectrophotometric ${ }^{16}$ analytical methods have been developed for the determination of efavirenz, but only one electroanalytical work was reported to date. ${ }^{17}$ With the recent advancements in properties of the adsorptive stripping voltammetry, new methodologies have been developed for adenine, thymine, guanine, ATP and DNA determinations employing alkaline solution with lower ionic strength as the supporting electrolyte. ${ }^{18-21}$ Using this alkaline electrolyte, the present work reports a new stripping voltammetric procedure for trace detection of efavirenz based on its adsorption at a thin-film mercury electrode. The advantages, instrumental parameters and possible limitations of this procedure are also explained in this work. Furthermore, the effects of a wide range of potentially interfering compounds, such as the antiviral drugs didanosine, acyclovir, nevirapine, indinavir, nelfinavir, saquinavir, lamivudine, zidovudine, some metal ions and ATP or DNA were examined.

\section{Experimental}

\section{Apparatus}

Differential pulse or cyclic voltammograms were obtained with an EG\&G PAR model 384-B Polarographic Analyser (Princeton Applied Research, Princeton, NJ, USA), equipped with an external cell and a Houston Ametek-DMP-40 series digital plotter. The working electrode was a glassy carbon electrode (GCE, $3.0 \mathrm{~mm}$ diameter, BAS-Bioanalytical Systems, Inc., West Lafayette, Indiana 47906, USA) with thin-film mercury, an $\mathrm{Ag} / \mathrm{AgCl}$ reference electrode with vycor tip and a platinum auxiliary electrode. A magnetic stirrer and stirring bar (Nalgene Cat. No. 6600-0010, Rochester, NY, USA) provided convective transport during the accumulation step.

\section{Preparing the thin-film mercury electrode}

The thin mercury film was deposited from a $10^{-2} \mathrm{~mol} \mathrm{~L}^{-1}$ $\mathrm{Hg}\left(\mathrm{NO}_{3}\right)_{2}$ solution, prepared by dissolution of $0.4 \mathrm{~g}$ of mercury(II) nitrate in $100 \mathrm{~mL}$ of an acidified Milli-Q water $\left(5 \% \mathrm{HNO}_{3}\right)$.
A glassy carbon electrode (GCE, BAS) was initially polished with alumina (PK-4, BAS) and then mounted with the help of a Teflon holder in a voltammetric cell provided with an $\mathrm{Ag} / \mathrm{AgCl}$ reference electrode, a platinum auxiliary electrode, and containing $1 \mathrm{~mL}$ of mercury(II) nitrate solution, $1 \mathrm{~mL}$ of $10^{-1} \mathrm{~mol} \mathrm{~L}^{-1}$ potassium nitrate solution and $8 \mathrm{~mL}$ of purified water. The solution was purged with nitrogen for $240 \mathrm{~s}$ to eliminate the oxygen initially present. Mercury plating was carried over for $5 \mathrm{~min}$ at a cell of $-0.9 \mathrm{~V}$. After checking that the electrode was plated properly, the set of electrodes was rinsed with water and a new clean cell containing the analyte solution was fitted.

\section{Reagents}

Water purified in a Milli-Q purification system (Millipore, Billerica, MA, USA) was used for all dilutions and sample preparations. All chemicals were analytical reagent grade. Efavirenz standard was used as received by the FarManguinhos-FIOCRUZ (Fundação Oswaldo Cruz, Rio de Janeiro-RJ). Stock solutions of 1000 ppm were prepared dissolving $50 \mathrm{mg}$ of the target reagent efavirenz into $5 \mathrm{~mL}$ of $2 \mathrm{~mol} \mathrm{~L}^{-1} \mathrm{NaOH}, 5 \mathrm{~mL}$ of ethyl alcohol and water until a volume of $50 \mathrm{~mL}$ was reached. Diluted efavirenz solutions of 100 or $10 \mathrm{ppm}$ were prepared daily using $5 \mathrm{~mL}$ of 1000 or $100 \mathrm{ppm}$ efavirenz into 5 or $25 \mathrm{~mL}$ of ethyl alcohol and water until $50 \mathrm{~mL}$ was reached. Stock solutions of other HIV drugs were prepared according to the procedure described for efavirenz. The didanosine and acyclovir stock solutions were prepared without the presence of ethyl alcohol. The solutions were stored in the dark at $4{ }^{\circ} \mathrm{C}$. A $1000 \mathrm{ppm}$ copper and other metals stock solutions (atomic absorption standard solution, Sigma-Aldrich Brasil Ltda.) were used, and diluted as required for standard additions. Stock solutions of $1000 \mathrm{ppm}$ of adenosine 5'-triphosphate, disodium salt hydrate (ATP) were prepared by dissolving $10 \mathrm{mg}$ of the reagent in $2 \mathrm{~mL}$ of diluted perchloric acid $\left(10^{-1} \mathrm{~mol} \mathrm{~L}^{-1}\right)$ with a subsequent solution heating at $70{ }^{\circ} \mathrm{C}$ during $30 \mathrm{~s}$. After heating, the sample was cooled down and diluted to $10 \mathrm{~mL}$ with water. Single-stranded calf thymus DNA (Cat. No. D-8899; Lot 43H67951) was used as received from Sigma. A $500 \mu \mathrm{g} \mathrm{DNA} / \mathrm{mL}$ stock solution (around $5 \mathrm{mg}$ per $10 \mathrm{~mL}$, lyophilized powder containing 63\% DNA) was prepared according to the procedure described for ATP. The final solution was stored at $4{ }^{\circ} \mathrm{C}$.

\section{Procedure}

A known volume $(10 \mathrm{~mL})$ of the supporting electrolyte solution $\left(2.0 \times 10^{-3} \mathrm{~mol} \mathrm{~L}^{-1}\right.$ sodium hydroxide $)$ was added to the voltammetric cell and degassed with nitrogen for $8 \mathrm{~min}$ 
(and for $60 \mathrm{~s}$ before each adsorptive stripping cycle). Initially, the condition potential (usually $-0.9 \mathrm{~V}$ ) was applied to the electrode for a selected time (usually $60 \mathrm{~s}$ ). Afterwards, the initial potential (usually $-0.10 \mathrm{~V}$ ) was applied to the electrode with a selected time (usually $240 \mathrm{~s}$ ), while the solution was slowly stirred. The stirring was then stopped, and after $30 \mathrm{~s}$, the voltammogram was recorded by applying a negative-going potential scan. The scan (usually at $50 \mathrm{mV} \mathrm{s}^{-1}$ ) was finished at $-0.90 \mathrm{~V}$, and the adsorptive stripping cycle was repeated with the same thin-film mercury. After the background stripping voltammograms had been obtained, aliquots of the efavirenz standards were introduced. The entire procedure was automated, as controlled by 384-B Polarographic Analyser. Throughout this operation, nitrogen was passed over the solution surface. All data were obtained at room temperature $\left(25^{\circ} \mathrm{C}\right)$.

\section{Results and Discussion}

\section{Parameters affecting the adsorptive stripping behavior of efavirenz.}

Figure 2 shows the linear adsorptive cyclic voltammogram for $0.1 \mathrm{ppm}$ of efavirenz in a $2.0 \times 10^{-3} \mathrm{~mol} \mathrm{~L}^{-1} \mathrm{NaOH}$ solution, using a pre-concentration time of $360 \mathrm{~s}$, with stirring, at $+0.05 \mathrm{~V}$. After equilibrium time of $30 \mathrm{~s}$, the linear cathodic cyclic voltammogram was recorded at $200 \mathrm{mV} \mathrm{s}^{-1}$. The efavirenz cathodic peak $\left(\mathrm{I}_{\mathrm{p}}\right)$ with half-width $\left(\mathrm{b}_{1 / 2}\right)$ of $200 \mathrm{mV}$ appears at $-0.36 \mathrm{~V}\left(\mathrm{E}_{\mathrm{p}}\right)$ and a single anodic peak is observed at $-0.28 \mathrm{~V}$ in the first scan.

In Figure 3, several chemical and instrumental parameters for the development of efavirenz determination

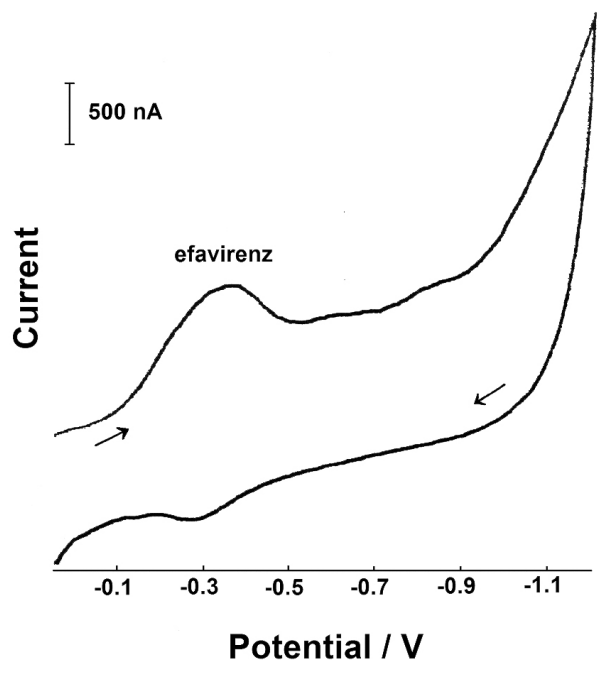

Figure 2. Linear adsorptive cyclic voltammogram of a $0.1 \mathrm{ppm}$ efavirenz solution in $2.0 \times 10^{-3} \mathrm{~mol} \mathrm{~L}^{-1} \mathrm{NaOH}$. Parameters: condition time of $60 \mathrm{~s}$ at $-0.90 \mathrm{~V}$, accumulation time of $360 \mathrm{~s}$ at $+0.05 \mathrm{~V}$ with stirring, scan rate of $200 \mathrm{mV} \mathrm{s}^{-1}$ and thin-film $\mathrm{Hg}$ electrode $(5 \mathrm{~min}$ at $-0.9 \mathrm{~V})$. analytical method in $2.0 \times 10^{-3} \mathrm{~mol} \mathrm{~L}^{-1} \mathrm{NaOH}$ at the mercury film electrode are shown. The effect of the amplitude pulse on the efavirenz differential pulse stripping peak current was examined over the $10-50 \mathrm{~V}$ range and the $\mathrm{pH}$ of electrolyte solution between 2-12 (adjusted by the addition of $\mathrm{HCl}$ or $\mathrm{NaOH}$ solutions). An increasing peak current was observed in the higher amplitude pulse and in a more alkaline medium solution. A careful control of the $\mathrm{pH}$ is necessary to examine efavirenz adsorptive stripping measurements. The peak current $\left(\mathrm{I}_{\mathrm{p}}\right)$ for the surfaceadsorbed efavirenz is directly proportional to the scan rate (v). A plot of $\mathrm{I}_{\mathrm{p}} v s . v$ was linear over the $10-500 \mathrm{mV} \mathrm{s}^{-1}$ range (correlation coefficient equal to 0.999 ) with a slope of $5.2 \mathrm{nA} \mathrm{s} \mathrm{mV}-1$. Thus, the analytical signal increases with the increase of the scan rate. However, at the scan rate of $500 \mathrm{mV} \mathrm{s}^{-1}$, the efavirenz peak becomes too broad. Consequently, a scan rate of $50 \mathrm{mV} \mathrm{s}^{-1}$ was chosen as an optimum value. The effect of accumulation potential was investigated and an increasing efavirenz peak current was observed from +0.05 to $-0.20 \mathrm{~V}$.

Figure 4 shows the dependence of the differential pulse current peak with the pre-concentration time. With $60 \mathrm{~s}$ of pre-concentration, the peak current for a $0.25 \mathrm{ppm}$ efavirenz solution was about 46 times larger than the corresponding peak obtained with a direct $(0 \mathrm{~s})$ response. The resulting plot of peak current $v s$. accumulation time $(0-60 \mathrm{~s})$ is linear (slope $10.31 \mathrm{nA} \mathrm{s}^{-1}$ and correlation coefficient equal to 0.997$)$.

\section{Quantitative utility}

The effective pre-concentration associated with the adsorption process results in a significant lowering of the limit of detection compared to the corresponding solution measurements. A limit of detectiont of $1.0 \mathrm{ppb}$ $\left(3.0 \times 10^{-9} \mathrm{~mol} \mathrm{~L}^{-1}\right)$ was estimated from quantification of $0.01 \mathrm{ppm}$ after a $10 \mathrm{~min}$ accumulation $(\mathrm{S} / \mathrm{N}=2)$. Thus, $10 \mathrm{ng}$ of efavirenz could be detected in the $10 \mathrm{~mL}$ of solution used.

The reproducibility was estimated by ten successive measurements on a stirred $0.25 \mathrm{ppm}$ efavirenz solution (other conditions: supporting electrolyte of $2.0 \times 10^{-3} \mathrm{~mol} \mathrm{~L}^{-1}$ $\mathrm{NaOH}$, condition time of $60 \mathrm{~s}$ at $-0.9 \mathrm{~V}$, accumulation time of $240 \mathrm{~s}$ at $-0.1 \mathrm{~V}$, final potential of $-0.9 \mathrm{~V}$, scan rate of $50 \mathrm{mV} \mathrm{s}^{-1}$, equilibrium time of $30 \mathrm{~s}$ and thin-film mercury electrode). The mean peak current was $74.5 \mathrm{nA}$ with a range of 70.4-78.0 nA and a relative standard deviation of $2.1 \%$. Such precision compares similarly with that reported for other compounds measured by adsorptive stripping analysis. ${ }^{18-21}$ The cathodic peak potential $\left(\mathrm{E}_{\mathrm{p}}\right)$ with half-width $\left(\mathrm{b}_{1 / 2}\right)$ remained the same at $-0.36 \mathrm{~V}$ and $200 \mathrm{mV}$, respectively. 

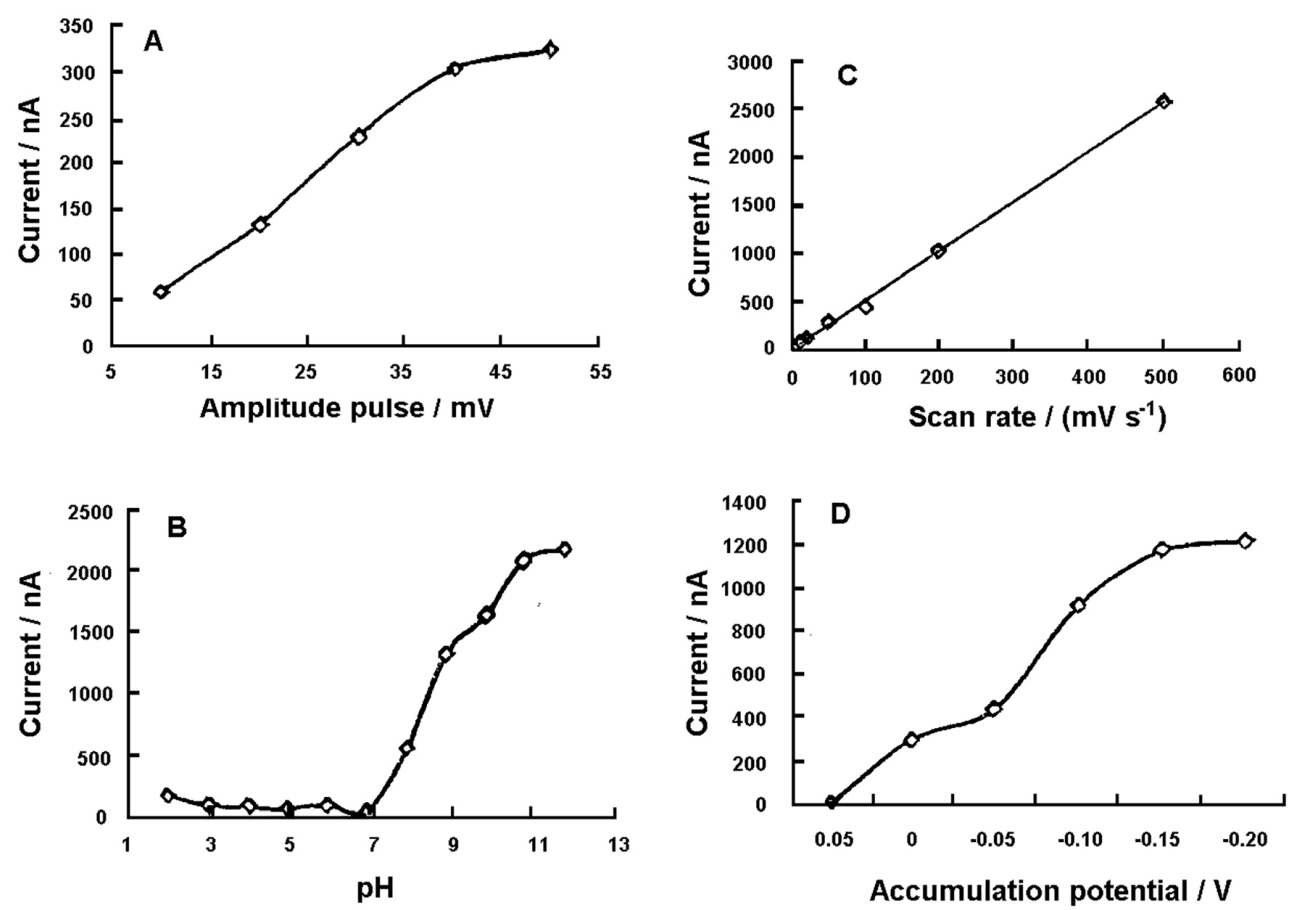

Figure 3. (A) Effect of amplitude pulse on the differential pulse adsorptive stripping voltammograms of $0.10 \mathrm{ppm}$ efavirenz solution in $2.0 \times 10^{-3} \mathrm{~mol} \mathrm{~L}^{-1}$ $\mathrm{NaOH}$. Parameters: condition time of $60 \mathrm{~s}$ at $-0.90 \mathrm{~V}$, accumulation time of $240 \mathrm{~s}$ at $-0.10 \mathrm{~V}$, scan rate of $50 \mathrm{mV} \mathrm{s}^{-1}$, equilibrium time of $30 \mathrm{~s}$ and thin-film $\mathrm{Hg}$ electrode $(5 \mathrm{~min}$ at $-0.9 \mathrm{~V}$ ). (B) Effect of $\mathrm{pH}$ on the differential pulse adsorptive stripping voltammograms of 1.0 ppm efavirenz solution. Parameters: pulse amplitude of $20 \mathrm{mV}$ and other conditions as the same for (A). (C) Effect of scan rate on the linear cyclic voltammograms of 0.25 ppm efavirenz in $2.0 \times 10^{-3} \mathrm{~mol} \mathrm{~L}^{-1} \mathrm{NaOH}$. Parameters: accumulation time of $240 \mathrm{~s}$ at $+0.05 \mathrm{~V}$, final potential of $-1.2 \mathrm{~V}$ and other conditions as the same for (B); (D) Effect of accumulation potential on the differential pulse adsorptive stripping voltammograms of $0.20 \mathrm{ppm}$ efavirenz solution in $2.0 \times 10^{-3} \mathrm{~mol} \mathrm{~L}^{-1}$ $\mathrm{NaOH}$. Parameters: pulse amplitude of $50 \mathrm{mV}$ and other conditions as the same for (A).
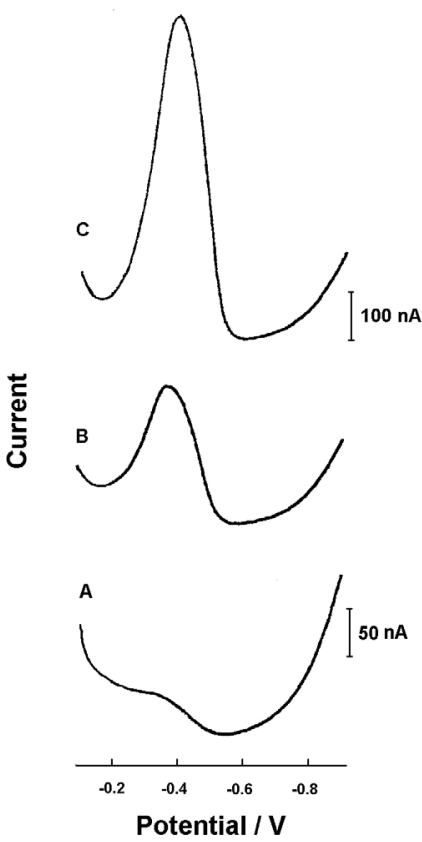

Figure 4. Effects of accumulation time at $-0.10 \mathrm{~V}$ on the differential pulse adsorptive stripping voltammograms of $0.25 \mathrm{ppm}$ of efavirenz in $2.0 \times 10^{-3} \mathrm{~mol} \mathrm{~L}^{-1} \mathrm{NaOH}$. The (A), (B) and (C) curves are relative to accumulation times of $0,30(50 \mathrm{nA}$ scale) and 60 (100 nA scale) s, respectively. Parameters: condition time of $60 \mathrm{~s}$ at $-0.90 \mathrm{~V}$, scan rate of $50 \mathrm{mV} \mathrm{s}^{-1}$, pulse amplitude of $50 \mathrm{mV}$, equilibrium time of $30 \mathrm{~s}$ and thinfilm $\mathrm{Hg}$ electrode $(5 \mathrm{~min}$ at $-0.9 \mathrm{~V})$.
Figure 5 displays voltammograms for increasing efavirenz concentrations ((A) 0.02, (B) 0.10 and (C) $0.20 \mathrm{ppm}$ ) after $240 \mathrm{~s}$ of accumulation. Well-defined stripping peaks (at $-0.38 \mathrm{~V}$ ) were observed between the efavirenz concentrations of 0.02 and $0.25 \mathrm{ppm}$. A non additive postpeak also was observed in approximately $-0.68 \mathrm{~V}$. The resulting plot of peak current $v s$. concentration is linear (slope equal to $4081 \mathrm{nA} \mathrm{ppm}^{-1}$, correlation coefficient of 0.999 ). Such linearity prevails as long as linear isotherm conditions (low surface coverage) exist. A separate experiment was performed to test linearity at the low concentration range resulting in well-defined stripping peaks between 0.01 and $0.06 \mathrm{ppm}$ of efavirenz concentration (accumulation time of $360 \mathrm{~s}$, final potential of $-0.9 \mathrm{~V}$ and other conditions are the same for results in Figure 5). The resulting plot of peak current $v s$. concentration also showed linearity (slope equal to $12044 \mathrm{nA} \mathrm{ppm}^{-1}$, correlation coefficient of 0.998 ).

Table 1 shows a summary of the optimized conditions for efavirenz determination by differential pulse adsorptive stripping voltammetry at the mercury film electrode.

Practical applications of differential pulse adsorptive stripping analysis may be affected by interferences due to the presence of metal ions and/or surface active compounds. With respect to the surface reaction, double layer changes 

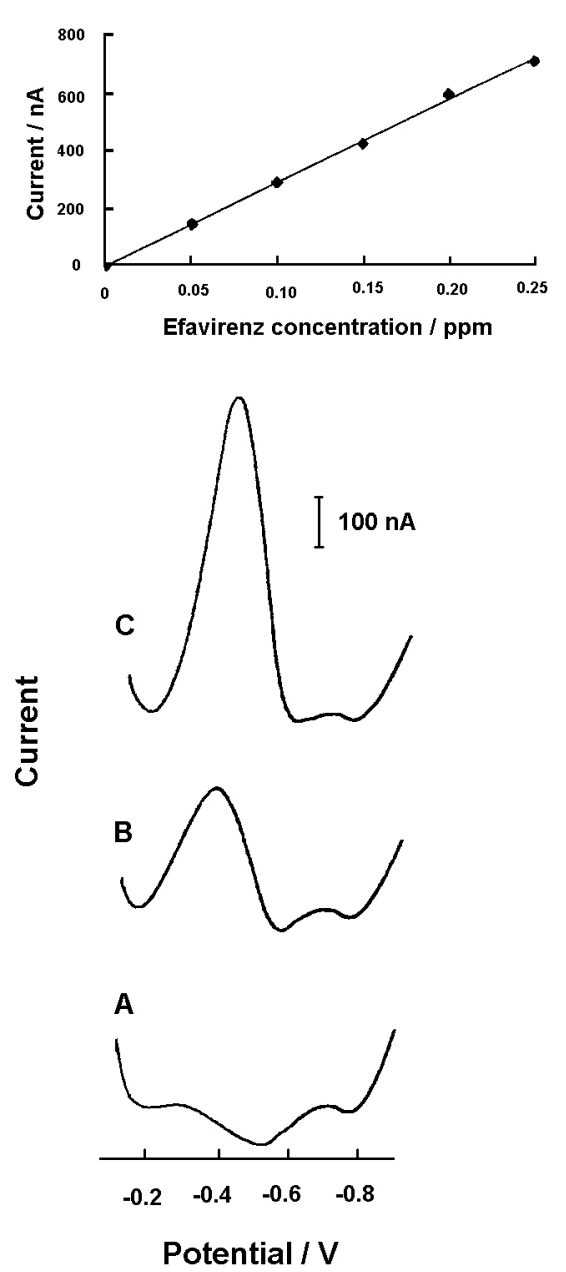

Figure 5. Differential pulse scan adsorptive stripping voltammograms obtained after increasing the efavirenz concentration in a solution of $2.0 \times 10^{-3} \mathrm{~mol} \mathrm{~L}^{-1} \mathrm{NaOH}$. The (A), (B) and (C) curves are relative to 0.02 , 0.10 and $0.20 \mathrm{ppm}$ of efavirenz, respectively. Parameters: accumulation time of $240 \mathrm{~s}$ at $-0.10 \mathrm{~V}$, condition time of $60 \mathrm{~s}$ at $-0.9 \mathrm{~V}$, scan rate of $50 \mathrm{mV} \mathrm{s}^{-1}$, final potential at $-0.9 \mathrm{~V}$, equilibrium time of $30 \mathrm{~s}$ and thin-film mercury electrode ( $5 \mathrm{~min}$ at $-0.9 \mathrm{~V}$ ). The resulting calibration plot in the concentration range $0.05-0.20 \mathrm{ppm}$ is also shown.

Table 1. Optimized conditions for efavirenz determination by differential pulse adsorptive stripping voltammetry at the mercury film electrode

\begin{tabular}{ll}
\hline Parameters & Optimized conditions \\
\hline Thin-film mercury electrode & $5 \mathrm{~min}$ at $-0.9 \mathrm{~V}$ \\
Efavirenz concentration range & $0.01-0.25 \mathrm{ppm}$ \\
Electrolyte & $2.0 \times 10^{-3} \mathrm{~mol} \mathrm{~L}^{-1} \mathrm{NaOH}$ \\
Scan mode & differential pulse \\
Initial potential & $-0.1 \mathrm{~V}$ \\
Final potential & $-0.9 \mathrm{~V}$ \\
Amplitude pulse & $50 \mathrm{mV}$ \\
Scan rate & $50 \mathrm{mV} \mathrm{s}$ \\
Condition potential & $-0.9 \mathrm{~V}$ \\
Condition time & $60 \mathrm{~s}$ \\
Accumulation potential & $-0.1 \mathrm{~V}$ \\
Accumulation time & $240 \mathrm{~s}$ \\
Equilibrium time & $30 \mathrm{~s}$ \\
\hline
\end{tabular}

or direct interactions deriving from these substances may inhibit or aid the accumulation of the analyte. Measurements of 0.10 or 0.15 ppm of efavirenz (conditions: supporting electrolyte of $2.0 \times 10^{-3} \mathrm{~mol} \mathrm{~L}^{-1} \mathrm{NaOH}$, condition time of $60 \mathrm{~s}$ at $-0.9 \mathrm{~V}$, accumulation time of 240 or $360 \mathrm{~s}$ at $-0.10 \mathrm{~V}$, final potential of $-0.9 \mathrm{~V}$, amplitude pulse of $50 \mathrm{mV}$, scan rate of $50 \mathrm{mV} \mathrm{s}^{-1}$, equilibrium time of $30 \mathrm{~s}$ and thin-film mercury electrode) were not affected by addition of up to $0.02 \mathrm{ppm}$ of iron(III) or cobalt(II), up to $0.12 \mathrm{ppm}$ of lead(II), up to $0.15 \mathrm{ppm}$ of cadmium(II), up to $0.16 \mathrm{ppm}$ of nickel(II) and up to $0.5 \mathrm{ppm}$ of zinc(II). At higher metal concentrations, the efavirenz peak increases in presence of iron(III) or cobalt(II) and indicates a possible formation of a Fe or Co-efavirenz complex. The zinc(II) or cadmium(II) in efavirenz solution presents a new and well-defined peak at $-0.63 \mathrm{~V}$. The more dramatic interference was observed with copper(II). The addition of $0.01 \mathrm{ppm}$ of copper(II) resulted in an increase of 4 times in efavirenz peak height.

Preliminary studies were developed for the determination of efavirenz in presence of other antiretroviral drugs for the treatment of human immunodeficiency virus (HIV): didanosine, acyclovir, nevirapine, indinavir, nelfinavir, saquinavir, lamivudine and zidovudine. It is worth noting that the latter two drugs constitute the medication Combivir ${ }^{\mathrm{TM}}$, administered in combination with efavirenz in HAART. Measurements of $0.10 \mathrm{ppm}$ efavirenz (conditions: supporting electrolyte of $2.0 \times 10^{-3} \mathrm{~mol} \mathrm{~L}^{-1} \mathrm{NaOH}$, condition time of $60 \mathrm{~s}$ at $-0.9 \mathrm{~V}$, accumulation time of $360 \mathrm{~s}$ at $-0.10 \mathrm{~V}$, final potential of $-0.9 \mathrm{~V}$, amplitude pulse of $50 \mathrm{mV}$, scan rate of $50 \mathrm{mV} \mathrm{s}^{-1}$, equilibrium time of $30 \mathrm{~s}$ and thin-film mercury electrode) were not affected by the addition of up to $0.10 \mathrm{ppm}$ of didanosine, acyclovir, nevirapine, indinavir, nelfinavir and saquinavir. A linear adsorptive cyclic voltammogram for $0.1 \mathrm{ppm}$ of free didanosine in a $2.0 \times 10^{-3} \mathrm{~mol} \mathrm{~L}^{-1} \mathrm{NaOH}$ solution showed a cathodic peak at $-0.56 \mathrm{~V}$. Measurements of 0.05 ppm efavirenz (supporting electrolyte, $2.0 \times 10^{-3} \mathrm{~mol} \mathrm{~L}^{-1}$ $\mathrm{NaOH}$ with $1 \% \mathrm{v} / \mathrm{v}$ of ethyl alcohol, accumulation time of $240 \mathrm{~s}$ at $-0.10 \mathrm{~V}$ ) were not affected by addition of up to $0.06 \mathrm{ppm}$ of lamivudine or zidovudine. After the addition of $0.08 \mathrm{ppm}$ of lamivudine or zidovudine, a new well-defined cathodic peak appears at $-0.62 \mathrm{~V}$. A synthetic mixture sample constitutive of $10 \mathrm{ppm}$ of efavirenz, $10 \mathrm{ppm}$ of zidovudine and $10 \mathrm{ppm}$ of lamivudine also was analyzed. The efavirenz $(0.05 \mathrm{ppm})$ cathodic peak appears at $-0.22 \mathrm{~V}$, while zidovudine $(0.05 \mathrm{ppm})$ with lamivudine $(0.05 \mathrm{ppm})$ appears at $-0.58 \mathrm{~V}$. The zidovudine and lamivudine peak is not affected by the presence of copper(II) (0.05 ppm).

Preliminary studies were also developed for the determination of efavirenz in the presence of DNA (Figure 6). The current measurements of $1.0 \mathrm{ppm}$ efavirenz (conditions: supporting electrolyte of $2.0 \times 10^{-3} \mathrm{~mol} \mathrm{~L}^{-1}$ 
$\mathrm{NaOH}$, condition time of $60 \mathrm{~s}$ at $-0.9 \mathrm{~V}$, accumulation time of $240 \mathrm{~s}$ at $-0.1 \mathrm{~V}$, final potential of $-0.9 \mathrm{~V}$, scan rate of $50 \mathrm{mV} \mathrm{s}^{-1}$, amplitude pulse of $50 \mathrm{mV}$, equilibrium time of $30 \mathrm{~s}$ and thin-film mercury electrode) were not affected by addition of up to $0.86 \mathrm{ppm}$ of DNA. A small positive shift of the efavirenz peak potential (from -0.38 to $-0.28 \mathrm{~V}$ ) was observed in presence of DNA. After the addition of $0.66 \mathrm{ppm}$ of DNA to a solution containing $1.0 \mathrm{ppm}$ of efavirenz, a DNA peak was also observed at $-0.67 \mathrm{~V}$. Well-defined stripping DNA peaks (at $-0.67 \mathrm{~V}$ ) were observed over the $0.66-0.96 \mathrm{ppm}$ concentration range. The resulting plot of DNA peak current $v s$. concentration (also shown in Figure 6) is linear (slope equal to $431.7 \mathrm{nA} \mathrm{ppm}^{-1}$, correlation coefficient of 0.999 ). Preliminary studies were also developed for the determination of efavirenz in presence of ATP. The current measurements of $0.05 \mathrm{ppm}$ of efavirenz (accumulation time of $240 \mathrm{~s}$ at $-0.2 \mathrm{~V}$, conditions are the same for the DNA experiment) were not affected by addition of up to $0.08 \mathrm{ppm}$ of ATP.
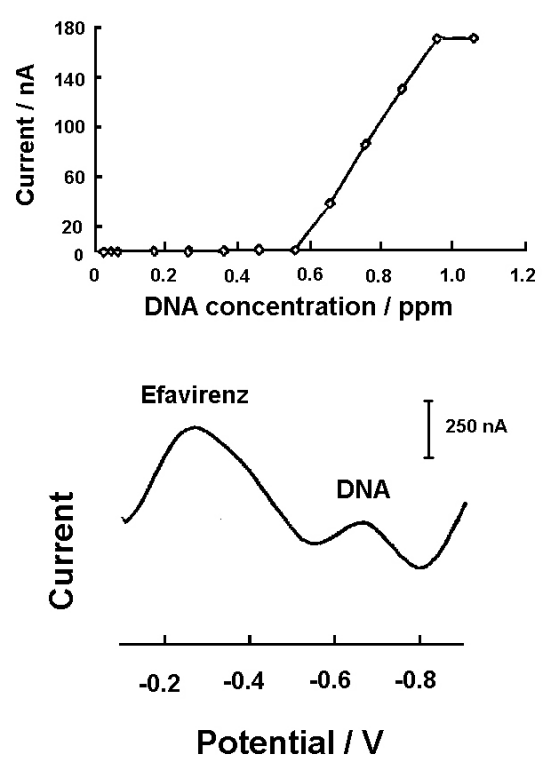

Figure 6. Differential pulse adsorptive stripping voltammogram of efavirenz $(1.0 \mathrm{ppm})$ in the presence of DNA $(0.96 \mathrm{ppm})$ in a solution of $2.0 \times 10^{-3} \mathrm{~mol} \mathrm{~L}^{-1} \mathrm{NaOH}$. Parameters: accumulation time of $240 \mathrm{~s}$ at $-0.10 \mathrm{~V}$, time of $60 \mathrm{~s}$ at $-0.9 \mathrm{~V}$, scan rate of $50 \mathrm{mV} \mathrm{s}^{-1}$, amplitude pulse of $50 \mathrm{mV}$, final potential at $-0.9 \mathrm{~V}$, equilibrium time of $30 \mathrm{~s}$ and thin-film $\mathrm{Hg}$ electrode $(5 \mathrm{~min}$ at $-0.9 \mathrm{~V})$. A plot of DNA current peak at $-0.67 \mathrm{~V}$ $v s$. DNA concentration is also shown. The experiment was carried out in the absence of oxygen.

\section{Conclusions}

An effective method for the determination of trace levels of the antiretroviral drug efavirenz was developed. The use of the simple and diluted alkaline electrolyte provided a sensitive and selective adsorptive stripping voltammetric method for efavirenz determination. An important point of difference with respect to the only electroanalytical work on efavirenz published to date is that the detection is made in the cathodic region $(-0.38 \mathrm{~V})$, instead of the anodic peak $(1.40 \mathrm{~V})$ used by Dogan-Topal et al. ${ }^{17}$ Furthermore, the previously reported methodology is appropriated for acidic media determinations ( $\mathrm{pH} 3.0$ was deemed an optimal value), while our system was designed to work in alkaline conditions. Interference studies indicate possible determination of efavirenz in the presence of other antiretroviral drugs used for the treatment of human immunodeficiency virus (HIV), like didanosine, nevirapine, indinavir, nelfinavir, saquinavir, lamivudine and zidovudine. These potential interferents were not taken into account by Dogan-Topal et al..$^{17}$ The efavirenz peak increases in the presence of iron(III) or cobalt(II), indicating a possible formation of $\mathrm{Fe}$ or Co-efavirenz complexes. The efavirenz and lamivudine or zidovudine stripping peaks are separated by $0.36 \mathrm{~V}$, and the efavirenz and DNA peaks by $0.39 \mathrm{~V}$. New methods using diluted alkaline solution as the supporting electrolyte and film mercury electrode modified in situ by metallic ions can be used for the detection of other drugs and DNA-intercalating dyes, as well as for aminoacids, peptides and proteins determinations. A similar study involving the bismuth film electrode ${ }^{22}$ is in progress.

\section{Acknowledgments}

The authors gratefully acknowledge CAPES (Coordenação de Aperfeiçoamento de Pessoal de Nível Superior, Brazil) and Ministério de Educación Superior of Cuba Republic (MES-Cuba) for their support to this work.

\section{References}

1. Young, S. D.; Britcher, S. F.; Tran, L. O.; Payne, L. S.; Lumma, W. C.; Lyle, T. A.; Huff, J. R.; Anderson, P. S.; Olsen, D. B.; Carroll, S. S.; Pettibone, D. J.; Obrien, J. A.; Ball, R. G.; Balani, S. K.; Lin, J. H.; Chen, I. W.; Schleif, W. A.; Sardana, V. V.; Long, W. J.; Byrnes, V. W.; Emini, E. A. L.; Antimicrob. Agents Chemother. 1995, 39, 2602.

2. Gotte, M.; Li, X. G.; Wainberg, M. A.; Arch. Biochem. Biophys. 1999, 365, 199.

3. Gallant, J. E.; Jesus, E.; Arribas, J. R.; Pozniak, A. L.; Gazzard, B.; Campo, R. E.; Lu, B.; McColl, D.; Chuck, S.; Enejosa, J.; Toole, J. J.; Cheng, A. K.; N. Engl. J. Med. 2006, 354, 251.

4. Villani, P.; Pregnolato, M.; Banfo, S.; Rettani, M.; Burroni, D.; Seminari, E.; Maserati, R.; Regazzi, M. B.; Ther. Drug Monitor. 1999, 21, 346.

5. Marzolini, C.; Telenti, A.; Buclin, T.; Biollaz, J.; Decosterd, L. A.; J. Chromatogr., B: Anal. Technol. Biomed. Life Sci. 2000, $740,43$. 
6. Matthews, C. Z.; Woolf, E. J.; Mazenko, R. S.; Haddix-Wiener, H.; Chavez-Eng, C. M.; Constanzer, M. L.; Doss, G. A.; Matuszewski, B. K.; J. Pharm. Biomed. Anal. 2002, 28, 925.

7. Takahashi, M.; Yoshida, M.; Oki, T.; Okumura, N.; Suzuki, T; Kaneda, T.; Biol. Pharm. Bull. 2005, 28, 1286.

8. Lemmer, P.; Schneider, S.; Schuman, M.; Omes, C.; Arendt, V.; Tayari, J. C.; Fundira, L.; Wennig, R.; Ther. Drug Monitor. 2005, 27, 521 .

9. Ramachandran, G.; Kumar, A. K. H.; Swaminathan, S.; Venkatesan, P.; Kumaraswami, V.; Greenblatt, D. J.; J. Chromatogr., B: Anal. Technol. Biomed. Life Sci. 2006, 835, 131.

10. Sailaja, A. L.; Kumar, K. K.; Kumar, D. V. R. R.; Kumar, C. M.; Yugandhar, N. M.; Srinubabu, G.; Chromatographia 2007, 65, 359.

11. Kankaanpaa, A.; Turtiainen, S.; Meririnne, E.; Arinierm, K.; Ristola, M.; Kuoppasalmi, K.; Ther. Drug Monitor. 2007, 29 , 513.

12. Dogan-Topal, B.; Ozkan, S. A.; Uslu, B.; Chromatographia 2007, 66, S25.

13. Notari, S.; Mancone, C.; Alonzi, T.; Tripodi, M.; Narciso, P.; Ascenzi, P.; J. Chromatogr., B: Anal. Technol. Biomed. Life Sci. 2008, 863, 249.
14. Barassi, A.; Pateri, F.; Musazzi, L.; d'Eril, G. M.; Clin. Chem. 2009, 55, A258.

15. Martin, J.; Deslandes, G.; Dailly, E.; Renaud, C.; Reliquet, V.; Raffi, F.; Jolliet, P.; J. Chromatogr., B: Anal. Technol. Biomed. Life Sci. 2009, 877, 3072.

16. Sankar, D. G.; Kumar, J. M. R.; Reddy, M. V. V. N.; Asian J. Chem. 2003, 15, 1856.

17. Dogan-Topal, B.; Uslu, B.; Ozkan, S. A.; Biosens. Bioelectron. 2009, 24, 2358.

18. Farias, P. A. M.; Wagener, A. de L. R.; Castro, A. A.; Anal. Lett. 2001, 34, 1295.

19. Farias, P. A. M.; Wagener, A. de L. R.; Castro, A. A.; Anal. Lett. 2001, 34, 2125.

20. Farias, P. A. M.; Wagener, A. de L. R.; Junqueira, A. A.; Castro, A. A.; Anal. Lett. 2007, 40, 1779.

21. Farias, P. A. M.; Castro, A. A.; Wagener, A. de L. R.; Junqueira, A. A.; Electroanalysis 2007, 19, 1207.

22. Wang, J.; Lu, J. M.; Hocevar, S. B.; Farias, P. A. M.; Oqorevc, B.; Anal. Chem. 2000, 72, 3218.

Submitted: September 23, 2010

Published online: June 9, 2011 